\title{
Characterization of two novel haloalkaliphilic archaea Natronorubrum bangense gen. nov., sp. nov. and Natronorubrum tibetense gen. nov., sp. nov.
}

\author{
Yi Xu, Peijin Zhou and Xinyu Tian
}

\author{
Author for correspondence: Yi Xu. Tel: +86010 62553628. Fax: + 8601062560912. \\ e-mail: xuy@sun.im.ac.cn
}

Institute of Microbiology, Academia Sinica, Beijing 100080, China

\begin{abstract}
Two haloalkaliphilic archaea were isolated from a soda lake in Tibet. The two strains, designated $A 3^{\top}$ and $\mathrm{GA33}^{\top}$, were Gram-negative, pleomorphic, flat, non-motile and strictly aerobic. Growth required at least $12 \% \mathrm{NaCl}$. Growth was between pH 8.0 and pH 11 with an optimum at pH 9.0-9.5. Cells were chemo-organotrophic. Polar lipids were $C_{20}-C_{25}$ derivatives of phosphatidylglycerol and phosphatidylglycerol phosphate. The nucleotide sequences of the 165 rRNA genes from the two strains were obtained by the analysis of the cloned rDNAs. On 165 rRNA phylogenetic trees, the two strains formed a monophyletic cluster. They differed from their closest neighbours, Halobacterium trapanicum and Natrialba asiatica, in polar lipid composition, as well as physiological and phenotypic characteristics. DNA-DNA hybridization indicated that the two strains belonged to different species of the same genus. The results indicated that the strains $\mathrm{A}^{33^{\top}}$ and $\mathrm{GA} \mathrm{A3}^{\mathrm{T}}$ should be classified in a new genus Natronorubrum gen. nov. as Natronorubrum bangense sp. nov. (strain A33') and Natronorubrum tibetense sp. nov. (strain GA33').
\end{abstract}

Keywords: Natronorubrum bangense gen. nov., sp. nov., Natronorubrum tibetense gen. nov., sp. nov., haloalkaliphilic archaea

\section{INTRODUCTION}

Halobacteria are among the most halophilic organisms known and require at least $1.5 \mathrm{M} \mathrm{NaCl}$ for their growth. They contain one order, Halobacteriales and one family, Halobacteriaceae (Grant \& Larsen, 1989). Before the 1970s, halobacterial taxonomy was mainly based on standard biochemical tests and morphology (Gibbons, 1974). At the end of the 1970s, however, the situation changed dramatically. 16S rRNA-DNA hybridization studies demonstrated that the halobacteria should be classified into nine clades of two groups (Ross \& Grant, 1985). The polar lipid compositions of these isolates had proven particularly useful in the classification of halobacteria (Ross \& Grant, 1985; Torreblanca et al., 1986). Polar lipid

Abbreviations: PG, phosphatidylglycerol; PGP, phosphatidylglycerol phosphate.

The GenBank/EMBLDDBJ accession numbers for the sequences reported in this paper are listed in the Methods. analysis and 16S rRNA-DNA hybridization studies not only produced groupings of six genera of halobacteria (Halobacterium, Haloarcula, Haloferax, Halococcus, Natronobacterium and Natronococcus) but also induced a further reclassification of some uncertain halobacterial species (Grant \& Larsen, 1989; Ross \& Grant, 1985). With the recent availability of more complete 16S rRNA sequences for many halobacteria, it became clear that there was even more diversity at the genus level within the family Halobacteriaceae (Kamekura \& Dyall-Smith, 1995; McGenity \& Grant, 1995). However, the use of phylogenetic parameters alone to describe taxa was considered not very accurate, and the combination of phylogenetic and phenotypic features (polyphasic taxanomy) is now necessary for the delineation of taxa (Oren et al., 1997).

In this paper, the complete $16 \mathrm{~S}$ rDNA sequences from two haloalkaliphilic archaea, strains $\mathrm{A} 33^{\mathrm{T}}$ and $\mathrm{GA} 33^{\mathrm{T}}$, are reported. The polar lipids of these isolates were also analysed, and the results of these biochemical tests were compared with those of other members of 
haloalkaliphilic archaea to determine the taxonomic positions for the strains $\mathrm{A} 33^{\mathrm{T}}$ and $\mathrm{GA} 33^{\mathrm{T}}$.

\section{METHODS}

Strains and culture conditions. Strains $A 33^{\mathrm{T}}$ and GA33 ${ }^{\mathrm{T}}$ were isolated from sediment ( $\mathrm{pH} 10,18^{\circ} \mathrm{C}$ ) of the Bange saltalkaline lake in Tibet. The isolation medium and the method for isolation was used as described previously (Tindall et al., 1980). These strains were grown aerobically at $37^{\circ} \mathrm{C}$ in a complex medium of the following composition $\left(\mathrm{g} \mathrm{l}^{-1}\right)$ casamino acids (Difco), 7.5; yeast extract (Difco), 10; trisodium citrate, $3.0 ; \mathrm{MgSO}_{4} .7 \mathrm{H}_{2} \mathrm{O}, 0.3 ; \mathrm{KCl}, 2 \cdot 0 ; \mathrm{Fe}^{2+}$ and $\mathrm{Mn}^{2+}$, trace; $\mathrm{NaCl}, 200 ; \mathrm{Na}_{2} \mathrm{CO}_{3}, 8 \cdot 0$.

The growth was monitored by $\mathrm{OD}_{600}$. Cell mobility and shape were examined by microscopy either without fixation under phase-contrast or with acetic acid fixation.

Biochemical characterization. The biochemical tests on strains $\mathrm{A} 33^{\mathrm{T}}$ and $\mathrm{GA} 33^{\mathrm{T}}$ were carried out in accordance with standard methods (Colwell et al., 1979; Holding \& Collee, 1971; Vreeland, 1993).

Lipid composition. The cellular lipids were extracted and analysed on silica gel plates (Kieselgel $60 \mathrm{~F}_{254}$; Merck) by one- and two-dimensional TLC (Ross et al., 1981; Ross, 1982). The core lipids were analysed by TLC, as described by Ross et al. (1981).

DNA base composition and DNA-DNA hybridization. DNA was isolated and purified as described previously (Zhou et al., 1994). The $\mathrm{G}+\mathrm{C}$ content was determined by thermal denaturation. DNA-DNA hybridization was carried out as described by Tindall et al. (1984) with a minor modification: DNA fragments were labelled with $\left[\alpha{ }^{32}\right.$ P $] \mathrm{dCTP}$ using the Boehringer Mannheim nick translation kit.

$16 S$ rRNA gene sequence. The methods used for DNA preparation, PCR amplification of the 16S rRNA gene and gene sequencing were described previously (Xu et al., 1995; Zhou et al., 1994).

Phylogenetic analysis of 16S rRNA sequences. The raw sequence dataset included nearly complete sequences for 40 halobacteria. The multiple sequence alignments were performed using CLUSTAL w version 1.7 (Thompson et al., 1994). The resulting aligned dataset contained information on 1451 nucleotide positions for 40 halobacteria. The phylogenetic analysis for this multiple sequence alignment was done with the TREECON for Windows version 1.2 (Van de Peer \& De Wachter, 1994) and the program package PHYLIP version 3.572 (Felsenstein, 1993). The phylogenetic tree was mainly constructed by the neighbour-joining method with the Kimura two-parameter calculation model in TREECON for Windows version 1.2. As references, other phylogenetic trees were also constructed with other methods in PHYLIP version 3.5 such as the parsimony and maximum-likelihood methods.

Nucleotide sequence accession numbers. The accession numbers for the 16S rRNA sequence for strains $\mathrm{A} 33^{\mathrm{T}}$ and $\mathrm{GA}^{2} 3^{\mathrm{T}}$ are $\mathrm{Y} 14028$ and AB005656, respectively. The 16S rRNA gene sequences of the test strains have the following GenBank/EMBL/DDBJ accession numbers (in parentheses): Halobacterium cutirubrum CCM 2088 (K02971); Halobacterium halobium ATCC 29341 (M11583); Halobacterium salinarum DSM 671 (M38280); Halobacterium sp.Y12 F.R.Valera (D14127); Haloarcula marismortui 1
ATCC 43049 ${ }^{\mathrm{T}}$ (X61688); Haloarcula marismortui 2 ATCC 43049 ${ }^{\mathrm{T}}$ (X61689); Haloarcula sinaiiensis 1 ATCC 33800 (D14129); Haloarcula sinaiiensis 2 ATCC 33800 (D14130); 'Haloarcula aidinensis' AS 1.2042 (AB000563); Haloarcula vallismortis 1 ATCC $29715^{\mathrm{T}}$ (U17593); Haloarcula vallis-

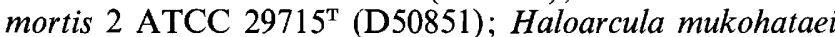
JCM 9738 ${ }^{\mathrm{T}}$ (D50850); Haloarcula argentinensis JCM 9737 (D50849); Haloferax volcanii ATCC 29605 (K00421); Haloferax mediterranei ATCC 33500 ${ }^{\mathrm{T}}$ (D11107); Haloferax gibbonsii ATCC 33959 ${ }^{\mathrm{T}}$ (D13378); Haloferax denitrificans ATCC $35960^{\text {T }}$ (D14128); Halorubrum saccharovorum NCIMB $2081^{\mathrm{T}}$ (U17364); Halorubrum lacusprofundi ACAM 34 ${ }^{\mathrm{T}}$ (U17365); Halorubrum sodomense ATCC $33755^{\mathrm{T}}$ (D13379); Halorubrum trapanicum NRC 34021 (X82168); Halorubrum sp. Ch2 ACM 3911 (L00922) ; Halorubrum vacuolatum JCM 9060 (D87972); Halobaculum gomorrense DSM 9297' ${ }^{\mathrm{T}}$ (L37444); Halococcus morrhuae 1 ATCC 17082 (X00662); Halococcus morrhuae 2 NRC 16008 (D11106); Halobacterium trapanicum JCM 8979 (D63786); Natrialba asiatica JCM 9576 ${ }^{\mathrm{T}}$ (D14123); Natrialba B1T JCM 9577 (D14124); Halobacterium trapanicum NCIMB 767 (D14125); L-11 F.J.Post (D14126); Natronobacterium SSL1 ATCC 43988 (D88256); Natronobacterium magadii NCIMB $2190^{\mathrm{T}}$ (X72495); Natronobacterium gregoryi NCIMB $2189^{\mathrm{T}}$ (D87970); Natronomonas pharaonis JCM 8858 (D87971); 'Natronobacterium innermongoliae' AS 1.1985 (AF009601) (Tian et al., 1997); Natronococcus occultus NCIMB 2192 (Z28378); Natronococcus amylolyticus Ah-36 ${ }^{\mathrm{T}}$ (D43628). The tree was rooted by using the $16 \mathrm{~S}$ rDNA sequence of Methanospirillum hungatei DSM 864 (M60880) as the outgroup.

\section{RESULTS AND DISCUSSION}

The two isolates stained Gram-negative, and were strictly aerobic, non-motile, flat and pleomorphic (triangular, square, disk-shaped and other polygonal shapes), as determined by phase-contrast microscopy. Cells lysed in distilled water. Both strains were catalase- and oxidase-positive and were able to use various kinds of sugars (glucose, sucrose, fructose, maltose and lactose). On agar plates, both strains formed red-coloured colonies about $2 \mathrm{~mm}$ in diameter after one week of culture. At $45^{\circ} \mathrm{C}$, strain $\mathrm{A} 33^{\mathrm{T}}$ grew optimally in the presence of $22.5 \% \mathrm{NaCl}(\mathrm{w} / \mathrm{v})$ at $\mathrm{pH} 9 \cdot 5$, whereas strain GA $33^{\mathrm{T}}$ grew optimally in the presence of $20 \% \mathrm{NaCl}$ at $\mathrm{pH} 9 \cdot 0$.

Alkaliphily, $\mathrm{G}+\mathrm{C}$ content and archaeal core lipid composition indicated that both strains were members of the haloalkaliphilic archaea, but biochemical tests together with morphological details distinguished the two strains from the other species of haloalkaliphilic archaea (Table 1).

The polar lipid composition showed that the two strains had, in common with other haloalkaliphilic archaea, a characteristic simple pattern. All haloalkaliphilic archaea characterized to date have $\mathrm{C}_{20}-\mathrm{C}_{25}$ diether core lipids of phosphatidylglycerol (PG) and phosphatidylglycerol phosphate (PGP) together with minor amounts of unidentified phospholipids. Therefore, the members of the haloalkaliphilic archaea could be distinguished from non-haloalkaliphilic archaea 
Table 1. Comparisons of phenotypic features of some members of haloalkaliphilic archaea

ND, Not determined.

\begin{tabular}{|c|c|c|c|c|c|}
\hline Characteristic & $\begin{array}{c}\text { Natronorubrum } \\
\text { bangense } \mathbf{A 3 3}^{\mathbf{T}}\end{array}$ & $\begin{array}{c}\text { Natronorubrum } \\
\text { tibetense } \\
\text { GA33 }^{\mathrm{T}}\end{array}$ & $\begin{array}{c}\text { Natronobacterium } \\
\text { gregoryi } \\
\text { NCMB 2198 }\end{array}$ & $\begin{array}{c}\text { Natronomonas } \\
\text { pharaonis } \\
\text { DSM } 2160\end{array}$ & $\begin{array}{c}\text { Natronobacterium } \\
\text { magadii } \\
\text { NCMB } 2190^{\mathrm{T}}\end{array}$ \\
\hline Cell shape & Pleomorphic & Pleomorphic & Long rod & Rod & Rod \\
\hline Gram stain & - & - & - & - & - \\
\hline Motility & - & - & - & + & + \\
\hline Colour & Red & Red & Red & Red & Orange-red \\
\hline Optimum $\mathrm{NaCl}(\%)$ & $22 \cdot 5$ & 20 & $17 \cdot 5$ & 20 & 20 \\
\hline Salt range $(\%)$ & $12-25$ & $12-30$ & $12-30$ & $12-30$ & $12-30$ \\
\hline Temperature $\left({ }^{\circ} \mathrm{C}\right)$ & 45 & 45 & $37-40$ & 45 & $37-40$ \\
\hline Optimum pH & $9 \cdot 5$ & $9 \cdot 0$ & $9 \cdot 5$ & $8 \cdot 5-9 \cdot 0$ & $9 \cdot 5$ \\
\hline $\mathrm{pH}$ range & $8 \cdot 0-11 \cdot 0$ & $8 \cdot 5-11 \cdot 0$ & $8 \cdot 5-11 \cdot 0$ & $8 \cdot 0-11 \cdot 0$ & $8 \cdot 0-11 \cdot 5$ \\
\hline $\mathrm{H}_{2} \mathrm{~S}$ from $\mathrm{Na}_{2} \mathrm{~S}_{2} \mathrm{O}_{3}$ & - & - & + & + & + \\
\hline Nitrate reduction & - & - & - & + & - \\
\hline Catalase \& oxidase & + & + & + & + & + \\
\hline Indole formation & + & + & ND & + & ND \\
\hline Starch hydrolysis & - & - & - & - & - \\
\hline Casein hydrolysis & - & - & - & - & + \\
\hline \multicolumn{6}{|l|}{ Tween hydrolysis: } \\
\hline Tween 40 & - & + & ND & ND & ND \\
\hline Tween 60 & - & + & ND & ND & ND \\
\hline Tween 80 & - & - & ND & ND & ND \\
\hline Gelatin liquefaction & - & + & - & + & - \\
\hline Sensitivity to erythromycin & + & + & + & - & + \\
\hline \multicolumn{6}{|l|}{ Growth stimulated by: } \\
\hline Acetate & + & + & + & - & + \\
\hline Glucose & + & + & + & - & - \\
\hline Fructose & + & + & + & - & - \\
\hline Sucrose & + & + & + & - & - \\
\hline Mannitol & - & - & + & - & - \\
\hline $\mathrm{G}+\mathrm{C}$ content $(\mathrm{mol} \%)$ & $59 \cdot 9$ & $60 \cdot 1$ & 65.9 & $64 \cdot 3$ & $63 \cdot 0$ \\
\hline \multicolumn{6}{|l|}{ Polar lipids: } \\
\hline PG and PGP & + & + & + & + & + \\
\hline Phospholipid1 & + & + & + & + & - \\
\hline Phospholipid 2 & - & - & - & - & - \\
\hline Phospholipid 3 & + & + & + & - & + \\
\hline
\end{tabular}

according to the major polar lipid composition (except Halorubrum vacuolatum). Different groups of halobacteria contain their own special polar lipid compositions. For example, besides the PG and PGP found in all halobacteria, TGD-1(tri-glycosyl diether), S-TGD-1(sulfated triglycosyl diether) and S-TeGD (sulfated tetraglycosyl diether) exist in Halobacterium; TGD-2 in Haloarcula; DGD-1(diglycosyl diether) and S-DGD-1 but no phosphatidylglycerosulphate (PGS) in Haloferax; S-DGD-3 and PGS but no DGD-1 in Halorubrum; S-DGD-1 but no PGS in Halobaculum; TGD-2 and S-DGD-1 but no PGS in Halococcus; $\mathrm{S}_{2}$ DGD-1 in Natrialba; a specific uncharacterized glycolipid in the unnamed taxa, Halobacterium trapanicum (NCIMB 767); but in main polar lipid compositions, only PG and PGP are found in Natronobacterium and Natronococcus, so polar lipid compositions could be used as a taxonomic indicator to some extent in halobacterial archaea.

We now report the sequences of 16S rRNAs from two haloalkaliphilic archaea, strains $\mathrm{A} 33^{\mathrm{T}}$ and $\mathrm{GA} 33^{\mathrm{T}}$, which contain 1475 and 1474 residues respectively. When compared with those of other halobacteria, the two strains showed reasonably high levels of similarity to their closest counterpart, Halobacterium trapanicum NCIMB 767 (93.3 and 92.7\%, respectively), and also to Natrialba asiatica $(91 \cdot 1$ and $92 \cdot 1 \%$, respectively), Natronococcus amylolyticus $(90.4$ and $91.7 \%$, respectively), Natronobacterium gregoryi (89.8 and $90.6 \%$, respectively), Natronobacterium magadii ( 88.7 and $90.2 \%$, respectively) and to Natronomonas pharaonis ( 84.2 and $82.8 \%$, respectively), in contrast with the $95.2 \%$ similarity between strains $\mathrm{A} 33^{\mathrm{T}}$ and $\mathrm{GA} 33^{\mathrm{T}}$. 


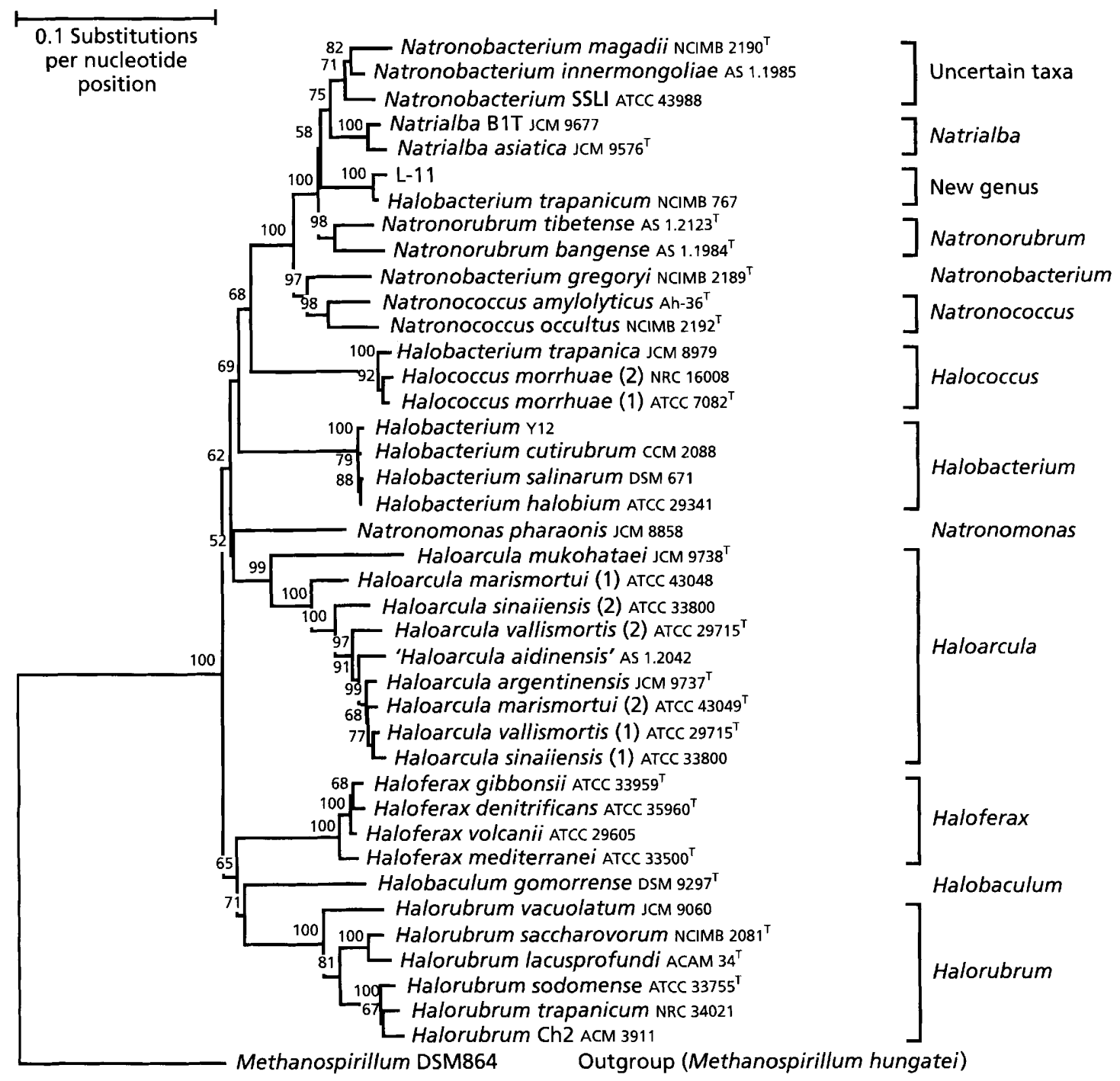

Fig. 1. The phylogenetic tree of halobacteria from their $16 \mathrm{~S}$ rRNA sequences. The tree was constructed by the neighbourjoining method and Kimura-two parameter calculation model. The numerals represent the confidence level from 100 replicate bootstrap sampling.

Phylogenetic analysis also showed the monophyletic position of the two strains in halobacterial archaea (Fig. 1). Among halobacterial archaea, the classification of the non-alkaliphilic halobacteria (the clade with core diether lipids of $\mathrm{C}_{20}-\mathrm{C}_{20}$ ) is comparatively straightforward (except for Halorubrum vacuolatum), and groups delineated by their polar lipid contents are consistent with the rRNA groups. However, the situation for the clade with core diether lipids of $\mathrm{C}_{20}-\mathrm{C}_{25}$ is unclear. This clade contains the nonalkaliphilic and alkaliphilic halobacteria, and was divided into five groups or genera by Kamekura et al. (1997) on the basis of 16S rRNA sequences: Natronomonas, Natronobacterium, Natrialba, Halococcus and an unnamed new genus. The members in some of these groups contain both the non-alkaliphilic and alkaliphilic halobacteria as well as different polar lipid compositions, which apparently does not agree with the principle of polyphasic taxonomy (Grant \& Larsen, 1989; Oren et al., 1997), the polar lipid composition being one of the important indicators in halobacterial taxonomy (Grant \& Larsen, 1989).

In our analysis, the two strains show the closest relationship with Halobacterium trapanicum NCIMB 767 in the phylogenetic tree (Fig. 1), but they can not be classified in the same genus due to the different polar lipid compositions, different morphology and optimum salinity for growth (Ihara et al., 1997). The results of the phylogenetic trees constructed by the parsimony and maximum-likelihood methods also supported this conclusion. That is, the two strains should not be classified with either Halobacterium trapanicum NCIMB 767 or Natrialba spp.; they ought to be placed in a new group. The DNA-DNA hybridization value $(35 \%)$, the low level of sequence 
similarity of $16 \mathrm{~S}$ rDNAs $(95 \cdot 2 \%)$ and the phenotypic differences (Table 1) between strains $\mathrm{A} 33^{\mathrm{T}}$ and $\mathrm{GA} 33^{\mathrm{T}}$ indicate that the two strains should belong to different species of the same genus. Thus, the two haloalkaliphilic archaea are classified into a new genus, Natronorubrum, and two novel species, Natronorubrum tibetense and Natronorubrum bangense, respectively.

\section{Description of Natronorubrum gen. nov.}

Natronorubrum [Na.tro.no.ru'brum. Gr. n. natron, derived from arabic natrun, soda (sodium carbonate); L. neut.adj. rubrum red; M.L. neut. n. Natronorubrum, the red of soda].

Gram-negative, pleomorphic flat-shaped (triangular, square, disk and other polygonal shapes) in favourable conditions. Colonies are pigmented red. Cells are nonmotile, strictly aerobic, oxidase- and catalase-positive. Growth requires at least $12 \% \mathrm{NaCl}$; cells are lysed in distilled water. Growth is between $\mathrm{pH} 8.0$ and $\mathrm{pH} 11.0$, with an optimum at $\mathrm{pH} 9 \cdot 0-9 \cdot 5$. Growth occurs in the temperature range $25-55^{\circ} \mathrm{C}$ with an optimal temperature of $45^{\circ} \mathrm{C}$. Chemo-organotrophic, many sugars (glucose, fructose, sucrose, maltose and lactose) are utilized, sometimes with acid production. Polar lipids are $\mathrm{C}_{20}-\mathrm{C}_{25}$ derivatives of PG and PGP. Type species is Natronorubrum bangense.

\section{Description of Natronorubrum bangense sp. nov.}

Natronorubrum bangense (ban.gen'se. M.L. neut. adj. bangense, from Bange, China).

Cells are pleomorphic, flat-shaped and uniformly stain Gram-negative. Growth occurs in media containing $12-25 \% \mathrm{NaCl}$, with an optimum at $22.5 \% \mathrm{NaCl}$. Growth is between $\mathrm{pH} 8.0$ and $\mathrm{pH} 11.0$, with an optimum at $\mathrm{pH} 9 \cdot 5$. Amino acids are utilized. Growth is stimulated by many sugars (glucose, fructose, maltose, sucrose and lactose). Indole is formed from tryptophan. Starch and casein are not hydrolysed. $\mathrm{H}_{2} \mathrm{~S}$ is not produced from thiosulfate. Gelatin is not liquefied. Tween 40,60 and 80 are not hydrolysed. The polar lipids are $C_{20}-C_{25}$ derivatives of PG, PGP and two uncharacterized minor phospholipids. The $\mathrm{G}+\mathrm{C}$ content of the DNA is $59.9 \mathrm{~mol} \%$. Type strain is A33 ${ }^{\mathrm{T}}$, deposited as AS 1.1984. (AS; Academia Sinica, China General Microbiological Culture Collection Centre, Zhong-guancun, Beijing 100080, China).

\section{Description of Natronorubrum tibetense sp.nov.}

Natronorubrum tibetense (ti.bet.en'se. M.L. neut. adj. tibetense from/of Tibet).

Cells are pleomorphic, flat-shaped and uniformly stain Gram-negative. Growth occurs in media containing $12-30 \% \mathrm{NaCl}$ with an optimum at $20 \% \mathrm{NaCl}$. Growth is between $\mathrm{pH} 8.5$ and $\mathrm{pH} 11.0$, with an optimum at $\mathrm{pH} 9 \cdot 0$. Amino acids are utilized. The growth is stimulated by many sugars (glucose, fructose, maltose, sucrose and lactose). Indole is formed from tryptophan. Starch and casein are not hydrolysed. $\mathrm{H}_{2} \mathrm{~S}$ is not produced from thiosulfate. Gelatin is liquefied. Tween 40 and 60 are hydrolysed but Tween 80 is not. The polar lipids are $\mathrm{C}_{20}-\mathrm{C}_{25}$ derivatives of PG, PGP and two uncharacterized minor phospholipids. The $\mathrm{G}+\mathrm{C}$ content of the DNA is $60 \cdot 1 \mathrm{~mol} \%$. Type strain is $\mathrm{GA} 33^{\mathrm{T}}$, deposited as AS 1.2123

\section{ACKNOWLEDGEMENTS}

We thank Dr A. Oren for his kind advice. This work was partially supported by the grant from National Natural Science Foundation of China.

\section{REFERENCES}

Colwell, R. R., Litchfield, C. D., Vreeland, R. H., Kiefer, L. A. \& Gibbons, N. E. (1979). Taxonomic studies of red halophilic bacteria. Int J Syst Bacteriol 29, 379-399.

Felsenstein, J. (1993). PHYLIP (Phylogeny Inference Package) version 3.5. Seattle: Department of Genetics, University of Washington.

Gibbons, N. E. (1974). Halobacteriaceae. In Bergey's Manual of Determinative Bacteriology, pp. 269-273. Edited by R. E. Buchanan and N. E. Gibbons. Baltimore, MD: Williams \& Wilkins.

Grant, W. D. \& Larsen, H. (1989). Group III. Extremely halophilic archaebacteria, Order Halobacteriales ord. nov. In Bergey's Manual of Systematic Bacteriology, vol. 3, pp. 2216-2233. Edited by J. T. Staley, M. P. Bryant, N. Pfennig and J. G. Holt. Baltimore, MD: Williams \& Wilkins.

Holding, A. J. \& Collee, J. G. (1971). Routine biochemical tests. Methods Microbiol 6a, 1-32.

Ihara, K., Watanabe, S. \& Tamura, T. (1997). Haloarcula argentinensis sp. nov. and Haloarcula mukohataei sp. nov., two new extremely halophilic archaea collected in Argentina. Int $J$ Syst Bacteriol 47, 73-77.

Kamekura, M. \& Dyall-Smith, M. L. (1995). Taxonomy of the Family Halobacteriaceae and the description of two new genera Halorubrobacterium and Natrialba. J Gen Appl Microbiol 41, $333-350$.

Kamekura, M., Dyall-Smith, M. L., Upasani, V., Ventosa, A. \& Kates, M. (1997). Diversity of alkaliphilic halobacteria: proposals for transfer of Natronobacterium vacuolatum, Natronobacterium magadii, and Natronobacterium pharaonis to Halorubrum, Natrialba and Natronomonas gen. nov., respectively, as Halorubrum vacuolatum comb. nov., Natrialba magadii comb. nov., and Natronomonas pharaonis com. nov., respectively. Int J Syst Bacteriol 47, 853-857.

McGenity, T. J. \& Grant, W. D. (1995). Transfer of Halobacterium saccharovorum, Halobacterium sodomense, Halobacterium trapanicum NRC 34021 and Halobacterium lacusprofundi to the Genus Halorubrum gen. nov., as Halorubrum comb. nov., Halorubrum sodomense comb. nov., Halorubrum trapanicum comb. nov. and Halorubrum lacusprofundi comb. nov. Syst Appl Microbiol 18, 237-243.

Oren, A., Ventosa, A. \& Grant, W. D. (1997). Proposed minimal standards for the description of new taxa in the Order Halobacteriales. Int J Syst Bacteriol 47, 233-238. 
Ross, H. N. M. (1982). The extremely halophilic archaebacteria. $\mathrm{PhD}$ thesis, University of Leicester, UK.

Ross, H. N. M. \& Grant, W. D. (1985). Nucleic acid studies on halophilic archaebacteria. J Gen Microbiol 131, 165-173.

Ross, H. N. M., Collins, M. D., Tindall, B. J. \& Grant, W. D. (1981). A rapid procedure for the detection of archaebacterial lipids in halophilic bacteria. J Gen Microbiol 123, 75-80.

Thompson, J. D., Higgins, D. G. \& Gibson, T. J. (1994). CLUSTAL $\mathrm{W}$ : improving the sensitivity of progressive multiple sequence alignments through sequence weighting, position-specific gap penalties and weight matrix choice. Nucleic Acids Res 22. 4673-4680.

Tian, X., Xu, Y., Liu, H. \& Zhou, P. (1997). New species of natronobacterium. Acta Microbiol Sin 37, 1-6.

Tindall, B. J., Mills, A. A. \& Grant, W. D. (1980). An alkalophilic red halophilic bacterium with a low magnesium requirement from a Kenyan soda lake. J Gen Microbiol 116, 257-260.

Tindall, B. J., Ross, H. N. M. \& Grant, W. D. (1984). Natronobacterium gen. nov. and Natronococcus gen. nov., two new genera of haloalkaliphilic archaebacteria. Syst Appl Microbiol $5,41-57$.

Torreblanca, M., Valera, F. R., Juez, G., Ventosa, A., Kamekura, M. \& Kates, M. (1986). Classification of non-alkaliphilic halobacteria based on numerical taxonomy and polar lipid composition, and description of Haloarcula gen. nov. and Haloferax gen. nov. Syst Appl Microbiol 8, 89-99.

Van de Peer, Y. \& De Wachter, R. (1994). TREECON for Windows: a software package for the construction and drawing of evolutionary trees for the Microsoft Windows environment. Comput Appl Biosci 10, 569-570.

Vreeland, R. H. (1993). Taxonomy of halophilic bacteria. In The Biology of Halophilic Bacteria, pp. 105-134. Edited by R. H. Vreeland \& L. I. Hochstein. Boca Raton, FL: CRC Press.

Xu, Y., Liu, H. D. \& Zhou, P. J. (1995). Nucleotide sequence of the 16S rRNA from an archaeon, Haloarcula aidinensis B-2. Acta Microbiol Sin 35, 77-85.

Zhou, P. J., Xu, Y., Xiao, C. S., Ma, Y. Q. \& Liu, H. D. (1994). Amplification of 16S rRNA genes from halobacteria by means of PCR technique. Acta Microbiol Sin 34, 6-8. 